616.728.3-002:616.718-089.85

\title{
変形性股関節症にたいする転子間骨切術の 生物学的意義に関する研究
}

\author{
岡山大学医学部整形外科学教室 (指導 : 児互俊夫教授)
}

奥田陸夫

[昭和 42 年 6 月 19 日受稿]

目

1. 緒 言

2. 実験方法

2.1 実験動物

2.2 手術方法

2. 3 Microa ngiography

2.4 SOFTEX 装置を屯ちいての Microangiogram

2.5 組織標本と SPALTEHOLZ 透明橴本

\section{I. 緒言}

変形性関節症は, 病理形態学的には関節構成体に おりる慢性の退行性・増殖性変化であつて，しだい にその形態が変化進行してゆくすのと定義されてい る. この変形性関節症のうちで, 頻度の高いとと, 治療方針の決定などについて最む興味のあるのは股 関節のそれであつて，相当古くより研究されている が，いまだに治療体系さえも充分にたてられていな い現状である。

変形性股関節症にたいする手術療法のうちで, 斬 子間骨切術の占める位置は重要であつて, その長 · 短所や適応などについて多くの報告がある，1894年 Kirmisson に初まる骨切術は種々の改良加加えられ， 1935年 Mc Murray の移動骨切術から1960年・1963 年Pauwels の内転・外轱骨切術にまで進歩している。

とてろでこの転子間骨切術の効果についてである が，多くの論文は機械的要䋕についてのみのべられ ており，生物学的要絜についての研究はすくない. しかし，ての生物学的要装について可成り重要視す る人もあり，私もこの点について関心をもち，奏験 動物として成熟家兔をむちい，転子間骨切術におけ る骨頭および骨中間部におよぼす影響について検し た. 人に扣ける症例においては大腿骨近位骨端軟骨 は完全に閉鎖しており，骨切衍が骨頭などに及ぼす 影響を同じくするために成熟家鬼をすちいたのであ
次

3. 実験成續

3.1 成熟家兔の大腿骨頭・骨中間部の血行および 組織学的所見

3.2 転子間骨切術後のもの

4. 変形性股関節症にたいする転子閒骨切術の症例

5. 文献的考察ならびに考按

6. 結 語

つて，骨端軟骨が残つていると骨頭と 中間部の血 液供給が直接連絡せず，骨切術後の血行状態が大分 違つてくるものと想像される.

動物実験では転子間骨切術をしたあとは，その組 織学的検討と Trueta の初めた Microangiography の 方法で血管の変化を追求し，教室で経験した変形性 股関節症にたいする転子間骨切術後のものと比較し， 転子間骨切術後における生物学的影響を中心に報告 してみたい。

\section{2. 実験方法}

\section{1 実験動物}

すべて成熟した家兔をあちいた．あらかじめ $3 \mathbf{~ k g}$ 以上のものを選んでおき， $\mathrm{x}$ 線撮影にて大腿骨近位 端の骨端線が完全に閉銷消失しているすののみを実 験に供した。

実験の予借練習に約20匹，本実験に約50匹を使用 した. しかし，麻酔や実験による失敗・標本作成や データをとるのに不適当のものが相当あり， $1 \sim 4$ 週のむのと $6 \cdot 8 \cdot 100$ 隔週のすのならびに鋼線を 骨䯣に適したのみのものを成功例が 4 匹以上になる ようしした。

\section{2 手術方法}

成熟家鬼をネンブタール静脈麻酔下で大腿骨近位 端を露呈し，枟子間骨切術をおこなつたあ之直径 2 $\mathrm{mm}$ のキルシュナー鎘線で骨䯣内固定をした. 左側 
は対象として残した．別に骨切術はせずに骨䯣内に 鋼線のみを通したのを作つた。

\section{3 Microangiography}

操作をしたあのおよび無操作のものを全麻醉下に 腹部大動脈を出し，点滴用チューブを挿入し，ヘパ

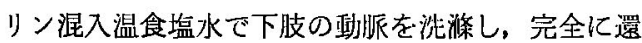
流食塭水が無色になつてから，15 25\%の Micropaque (Demancy \& Co. Ltd.) 食塩水浴解液に $1 \sim 2$ 96のBerlin Blue を混じたものをゆつくりと注入し た. 150〜250cc も入れると下股の皮筩が青くなり， 爪を傷つけると造影㓣が流出するようになれば流入 を中止する．上下の血管を結絷し，骨盤の一部をつ けたままで両大腿骨近位端を摘出する。

一度冷凍室で Micropaque を固め, ついで $10 \%$ ○ ホルマリン液につけけ，そのあ之10\%位のトリクロ 一ル酢酸で完全に脱灰する。

2.4 Softex 装置をもちいての Microangiogram

充分脱灰した骨標本について，全体および綐割 $1 / 2$ 標本を Softex CMB 型装䈯をもちいて撮影した。感 光材料としては, 富上 SOFTEX フィルムの H.S. と F.G，使用した。撮影条件はそれれ゙れ異るが， H.S. のフィルムで $16 \mathrm{KV} \cdot 1 \mathrm{~mA} \cdot 5 \sim 10$ 分間照射 した. 標本までの距離は $35 \mathrm{~cm}$ で，F. G. のフィルム ではこの10倍以上の照射が必要であつた. SOFDOL 現象をおこない，普通のように手忙・キャビネ版に まで引伸した。

2.5 組織標本之 SPALTEHOLZ の透明標本 microangiogramに利用した脱灰骨標本をツェロ

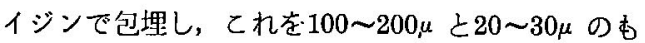
のの 2 椣類の標本とした．前者引 SPALTEHOLZ の 標本へ，うすいものは H-E 重染色艺おこなつた。

SPALTEHOLZ の標本は一般組織仙何等染焦甘ず， 徽細な血管を探るのに適しており，すこし原いので 三次元的に血管が近求できる。

\section{3 実 験 成綪}

3.1 成熟家鬼の大泼骨頭・骨中間部の血行お よび組織学的所見

成熟家兔の骨頭動挀は腹側より入るもの之背侧よ りのあのがある。このうちで腹側よりものは Microangiogram であよく認められ，骨頭に侵入してから は $3 \sim 4$ 本に分岥して背側们向い，さらに頸部より 上行するあの上交又する，背側より骨頭へ入るあの は細く，骨頭背侧へ達した血管も大忶子へは比校的
太いのを出している，したがつて，骨頭内での分布 あ腹側のあのがはるかに優勢である。

骨中間部は，外側大腿回旋動脈之内側大腿回旋動 师の枝で栄養されている，外側のそれは，大腿骨頸 部でその腹側前方において骨中間部に侵入し，背方 へ進みながら上下に分枝する。乙この動脈の分布領域 は骨中間部でその前方に限られ，领围は比校的狒 い. 内側大腿回旋動脈は外側のそれよりやや遠位で 腹側後方より骨中間部へ穿通する。骨中間部之転子 部でその前方のすてしを除いて大半を支配してい る. 一度上行して，その主流は大転子，第 3 転子へ 向つて下行する，骨中間部の篓養ということにおい ては最む大切なものである，大腿骨骨幹栄養動脈は 内転筋附着部より斜红骨皮質を貫き，上下行枝江分 かれる. 上行枝は $5 \sim 6$ 本になつて骨中間部们向つ て上行するが，幾分前外側方に片寄つている．この 栄養動脈は骨切術によつて完全に切断されるあので， 直接の影響はての動眽の支配領域が受けるわけであ るる(図 1)。

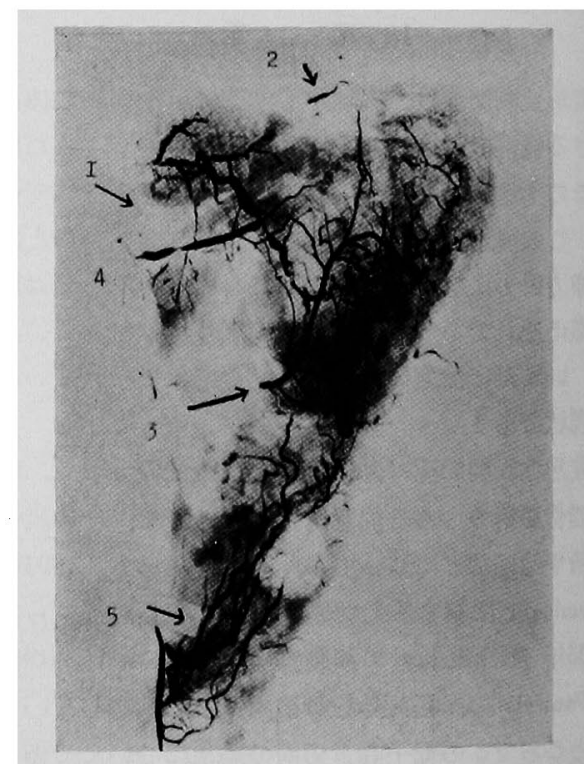

図 1 a. 成熟家鬼大腿骨近位端の動脈

(全 標 本)

(Microangiogram)

1 ; 骨頭動脈腹側板

2 ; " 背側板

3 ; 内側大腿骨回捗動脈

4 ; 外側 " "

5 ; 大腿骨骨幹栄羕動脈

骨頭の円跑帯よりの血管は，骨頭の近くまでは来 ているのが侵入はしない（図2）。 


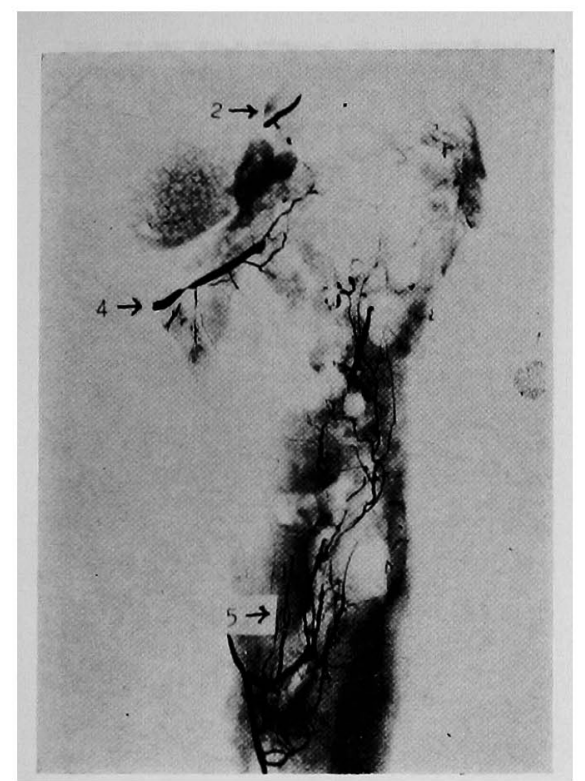

図 1 b. 成熟家鬼大腿骨近位端の動脈 (欮割 $1 / 2$ 前半)

(Microangiogram)

1 ; 骨頭動脈腹側板

2 ; " 背側板

3 ; 内側大腿骨回旋動脈

4 ; 外側 " "

5 ; 大腿骨骨幹栄養動脈

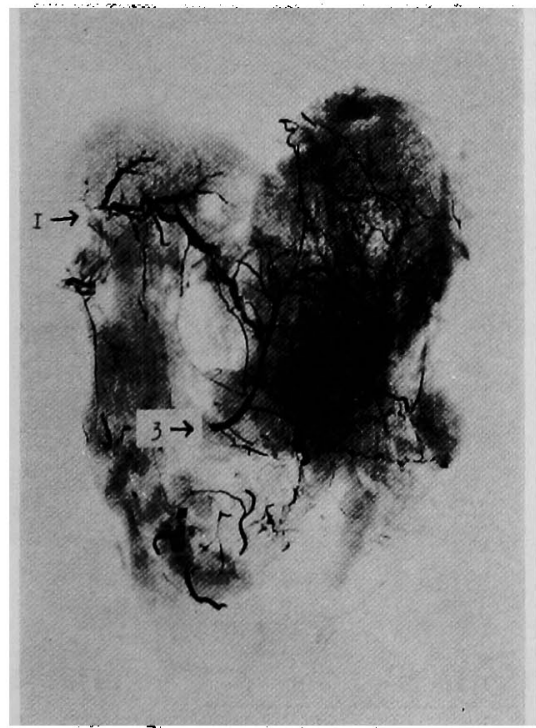

团 1 c. 成熟家鬼大腿骨近位端の動脈 (縱割 $1 / 2$ 後半)

(Microangiogram)

1 ; 骨頭動脈腹側板

2 ; " 背側板

3; 内側大腿骨回旋動脈

4 ; 外側 " "

5 ; 大腿骨骨翰栄養動脈

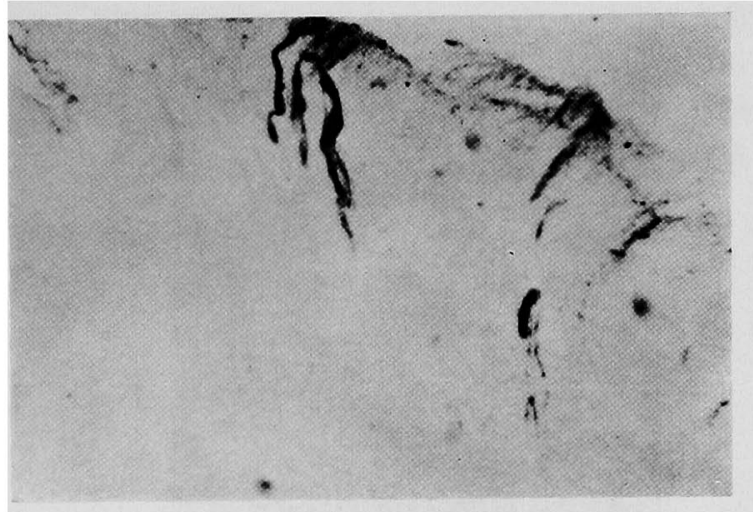

図 2 骨頭円勒葷の血管

骨頭円勒率の血管は骨の栄養に関与するまでは侵入して いない。

(SPALTEHOLZ の標本 $\times 100$ )

大腿骨頭を包む関節軟骨洛終生骨化ぜずに残万む ので, 3 層よりなつている，最表層は細胞は扁平で 核は比較的丸い，中閒層ではこの亚びが次第に垂直 になり，細胞もすとし大きくなつてくる，最深部は H-E 染色にて青く浱染する（図 3 ）。

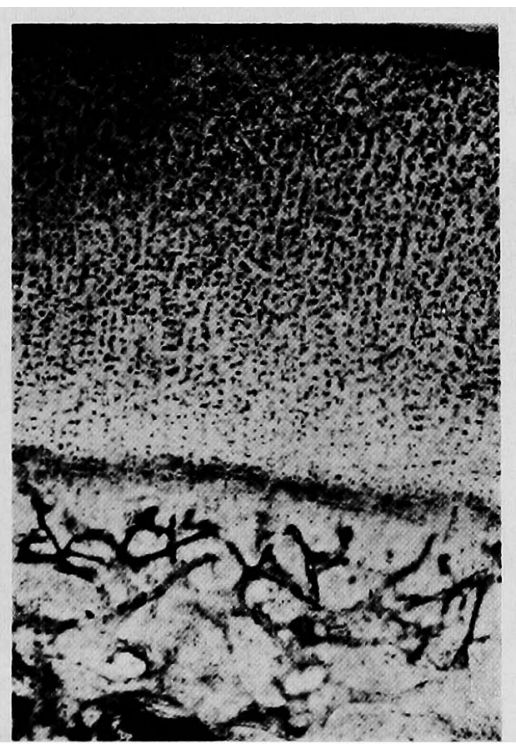

図 3 関 節 軟 骨

正常の関節㳄骨で表層より深層まで整然としている $(\mathrm{H} \cdot \mathrm{E}$ 染色 $\times 50)$

sub-chondral まで骨細管が網目状に侵入し，この 下にある骨端部の骨梁の閌には毛細血管と静挀洞が 整然と业んでいる。どの部分す血球が枃一的に䒕满 している(図4).

骨端部と骨中間部の間には，成長期における骨端 軟骨の残遣物として横走の骨梁がある，血管がここ 


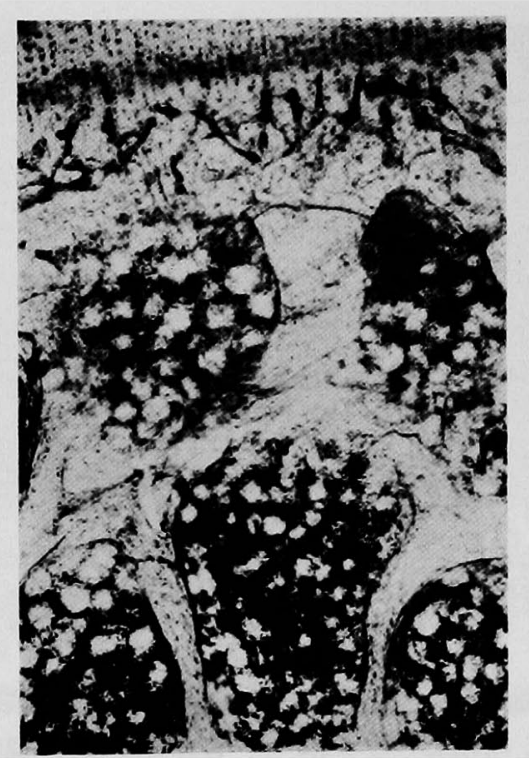

図 4 骨 端 部

関節軟骨より骨端とかけての骨梁と靜脈洞の状態 (H. $\mathrm{E}$ 染色 $\times 50)$

を貫通していて，血行循環における壁はなくなつて おり，幼若なむのとの差異の最も大きいものである (図 5 ).

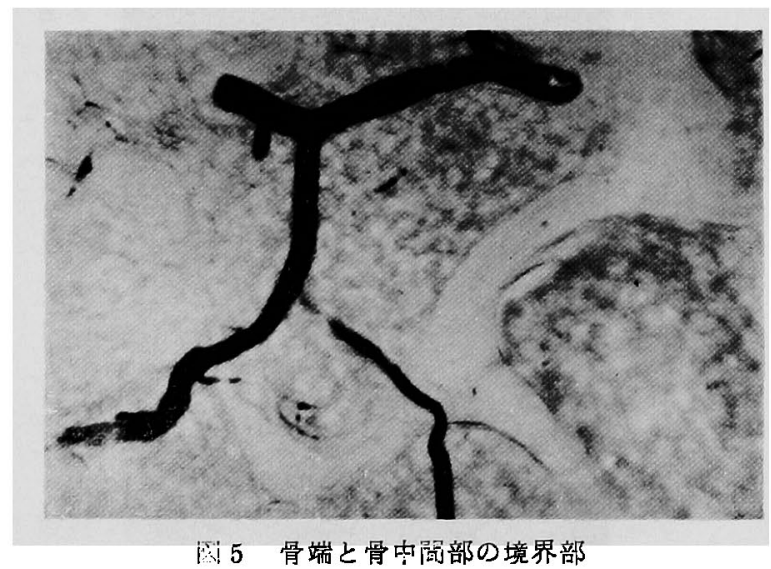

以前骨端軟骨のあつた場所を穿通する血管

(SPALTEHOLZ の標本 $\times 100$ )

骨中開部はこの横走骨梁より下を指しており，䃑 腔には骨端部より血球に富んでいる（図6).

3.2 転子閒骨切術後のもの

1) Microangiogram, SPALTEHOLZ の透明標本

○1 週間目，骨中間部では，内側大腿回琁怔挀領 域より遠位にかかては阻血状態であつて，わずかに 細い血管が系状に造影されているにすぎない（図 7 ). SPALTEHOLZ の 標本でみても，回旋怔版

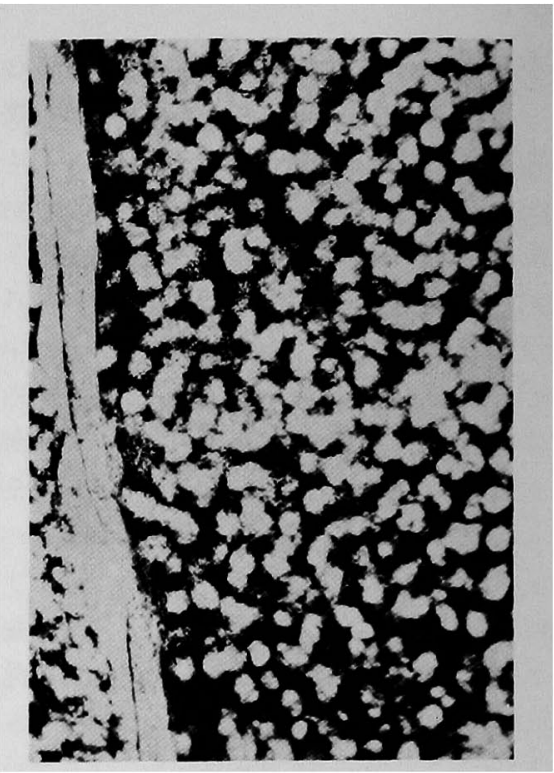

図6 骨中間部の䯣 腥 靜脈洞は綺䇛で均一的に血球で充満している

(H.E染色 $\times 50)$

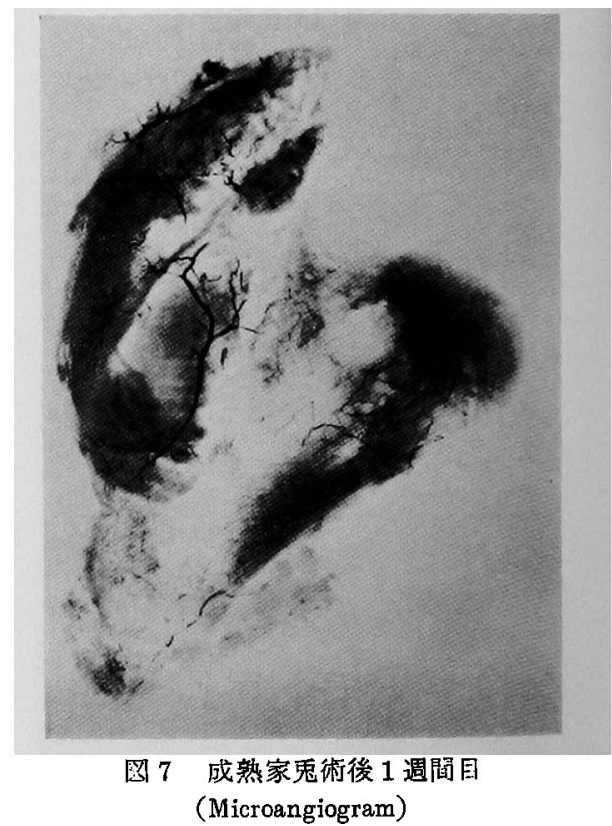

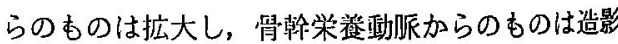
剂が入らず阻血状態になつているのが判る，又骨頭 腹側より入る血管も多少の代傥性肥大があるようて ある。

○2 週間目，血管に蛇行性拡大がみられる，主玟 より分支したものが主枝の太さに近付き，主枝との 区別がつきにくくなつてきている（図8）.内側大 腿回旅澌挀の分枝のちでで沫稍へ向うものは束をな 


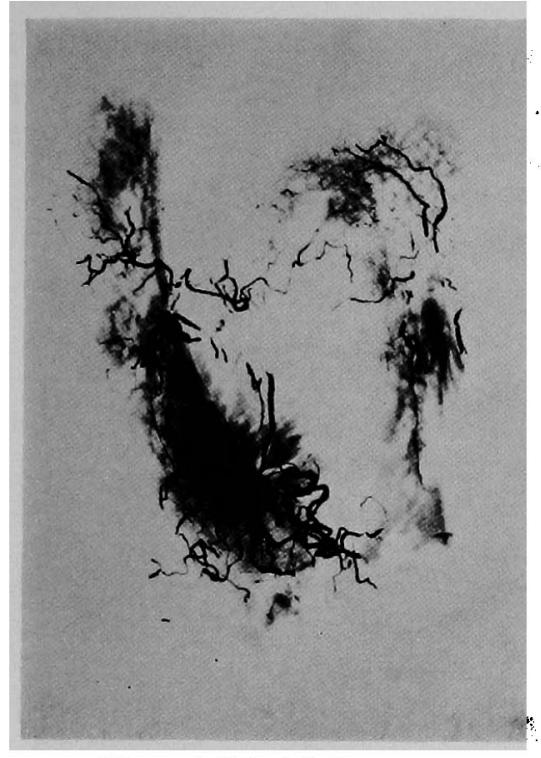

図 8 成熟家鬼術後 2 週間目 (Microangiogram)

している，血管の太さでは第 3 転子基部辺りのもの が最す太く，骨頭の腹側よりのあのも背側比して はる加に太い。

○3 週間目 この週のむのはさらに血管の変化が 著明である. 各部分の血管は蛇行拡大が著るしく， 太さにおいては主枝と分枝之は区別が殁んどできず， 急に細くなつてしまう，回旋㲜脈群もそうであるが， 骨頭腹側よりの血管 は非常に太く（図 9 ),

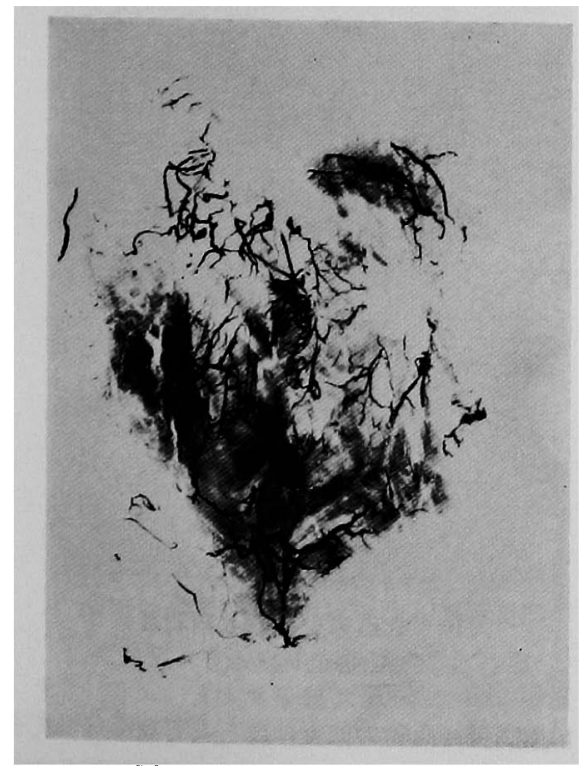

图 9 成熟家鬼術後 3 週間目 (Microangiogram)
背側より骨頭に入るものは Spalteholz 標本でみる 之細いけど数をましていて，矢張り血行循環はまし ている，腹側の関節䟠附着部では血管の拡大・增殖 がある（図10），骨中閒部では血管拡大充血部之阻 血状態のとてろが剑りあつている.

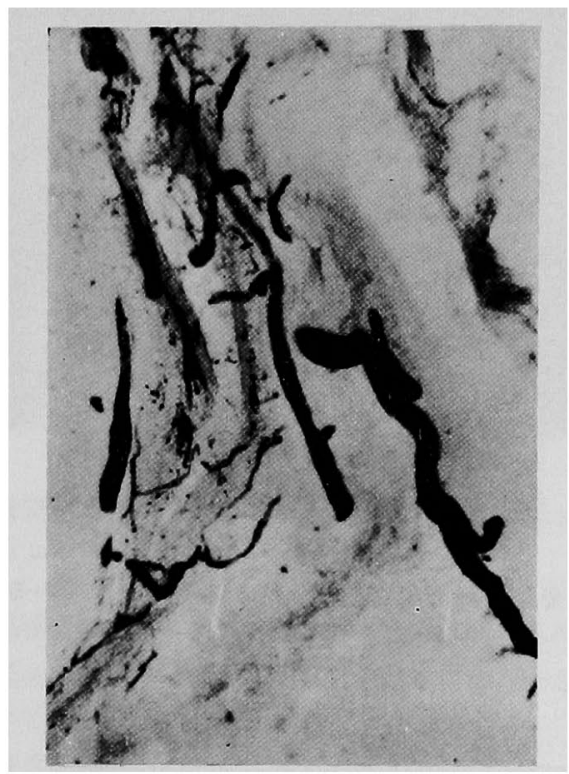

圈10 術後 3 週間の関節翼附着部

腹側の関節罡附着部では血管の増殖と拡大がよくみ られる。

(SPALTEHOLZ $の$ 標本 $\times 100$ )

○4週閌目 反応性の血管拡大はその頂点に達し た感がある．太さでは主枝と分枝は全く区別できず， 全体的にも揃つてきている，頸部や第 3 枟子から遠 位へ向う血管ば太くて揃つており，横の連絡ができ 初めている，遠位部においては增殖性血管ができ， 切口近くの血管は遠位骨片と直接連絡ができている ようである（図11），骨頭の血管では，腹 側のあの は非常に太くなつているに反して，背側よりのむの はパンヌス状に給合織の増殖があり，ここに血管増 殖があり骨頭へ入つてゆくけれどあ一大腿骨大転子 へ向うのが太い割りに一細くて数むすくない（図 12）。骨中開部では，血管の拡大がみられる一方阻 血状態が続いてる。

○6 週閒目，骨頭では，その腹側より穿通進行す る動脈がよく目立ち，骨頭を横に栄鉴貫通したのち， 頸部を経て本子部へ連絡している。しかし，反応性 に㤞行拡大する時期ははその读を越し，分枝はやや 細く，血管増生が目立つている（図13），遠位にあ る骨片とは連絡が密になつてきていて，骨頭動哌は パンヌス快增殖より血管侵入の様子がみられる，骨 


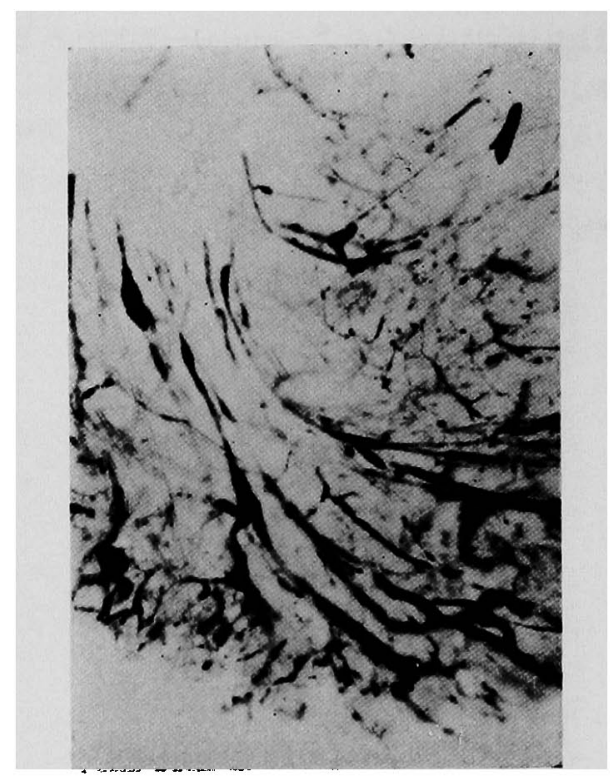

圈11 術後 4 週間目の骨切部附近 骨切部附近では遠位骨片と連絡ができている (SPALTEHOLZ の標本 $\times 100)$

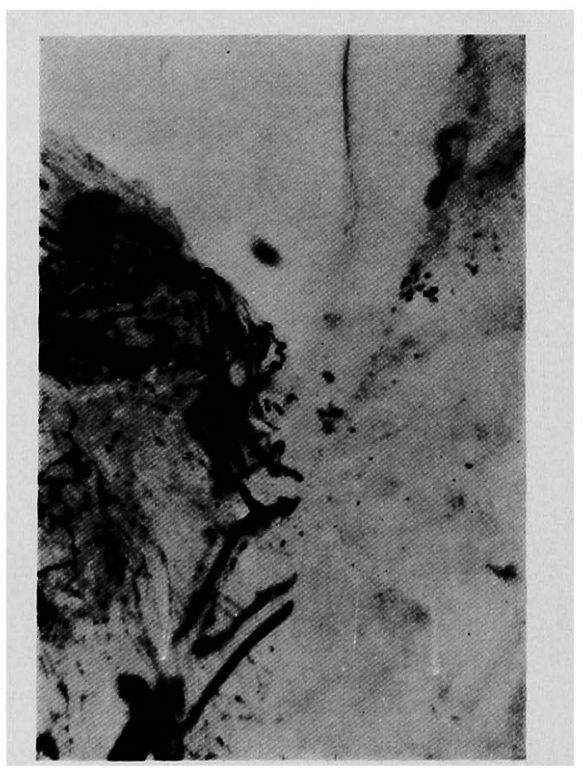

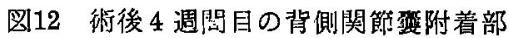

外側関節芷附着部から大転子への血管は太いが骨頭 へのものは細くて少くない

（SPALIEHOLZ の標本 $\times 100 ）$

中間部では，症例によつては強い阻血些のとてろが できて，周囲の血管拡大增殖をうながしている

○8週間目，骨頭之骨中間に加けての血液循環 状態は密であつて，大転子より遠位への連絡は太さ の揃った血管でなされ，努定した状態となつてきて

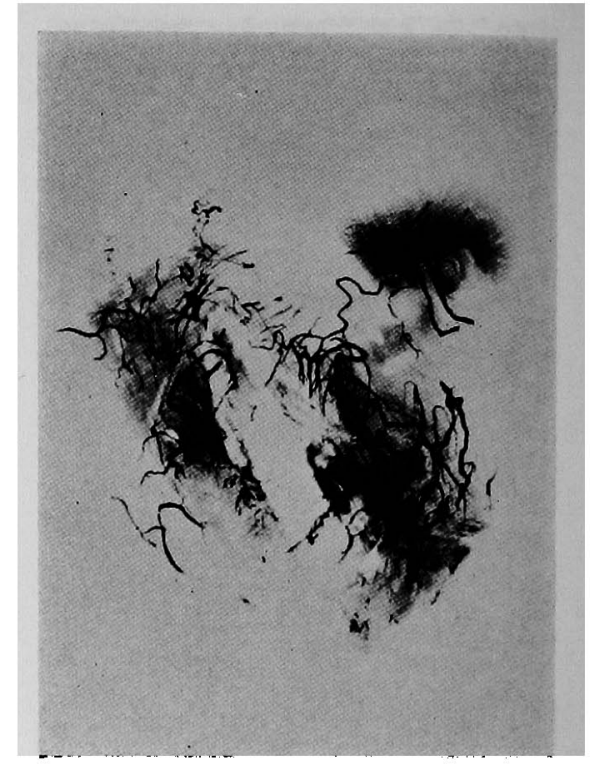

図13 战㜪家鬼術後 6 週間目 (Microangiogram)

いる．分枝の太さは主枝のもの之は相当の差がでて きており，拡大していた血管も大分元に加えつてき ていることが想像される，骨頭血管の拡大はまだ続 いているが棸く，骨中閂部のあのあ蛇行性がすくな く太さむ正常近くなつてきている.

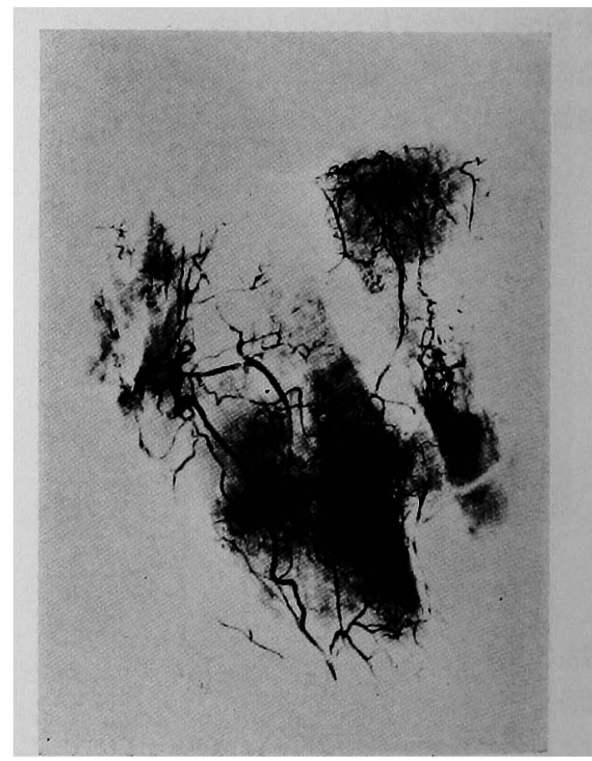

図14 成熟家鬼術後 8 週間目 (Microangiogram)

○10週間目，血管の拡大ははとんどなくなつてき ており，主枝と分枝との比む正常に近く，幾分血管 に乱れはあるが，骨切術による血管拡大の效果は消 
える寸前であろう，骨中間部では，太い前よりあつ た血管から新生血管が完成しているのが見られる (図15).

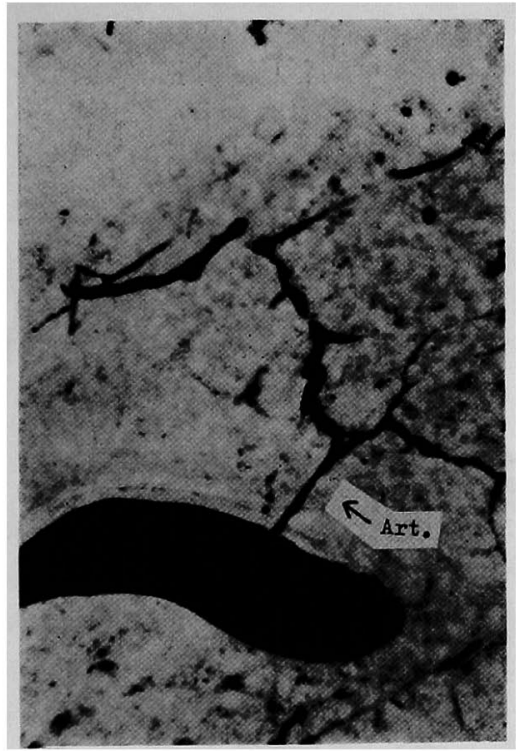

図15 術後10週目の新生血管

骨中閶部で前よりあつた太い血管ら新生血管が完成 している。

Art. 新生細血管

(SPALTEHOLZ 標本 $\times 100)$

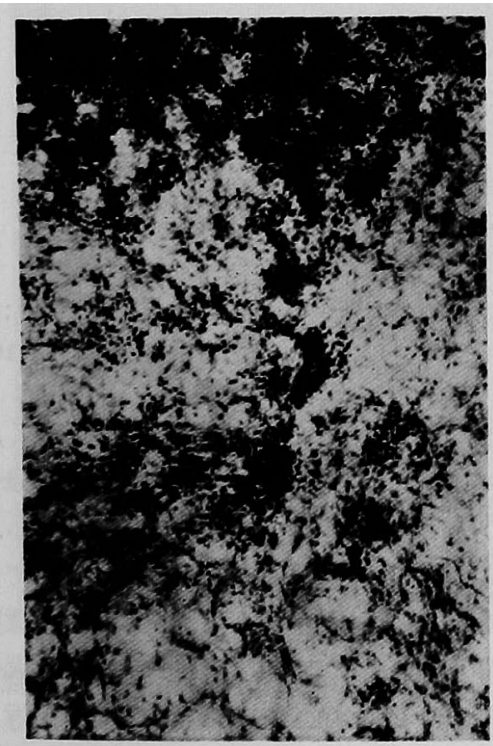

図16 術後 1 週間目に㧠ける骨中間部 充血部より阻血部へ移行するととろ （H・E染色 $\times 100 ）$

2) 組織学的所見

○1 週闪目 関節㳄骨, 骨端部には影響はない.
骨中間部では，その近位端においては变化はないが， 遠ざかるに従い充血が強くなり，さらに進むと反対 に阻血となつてくる (16図)。乙の境界線は内側大

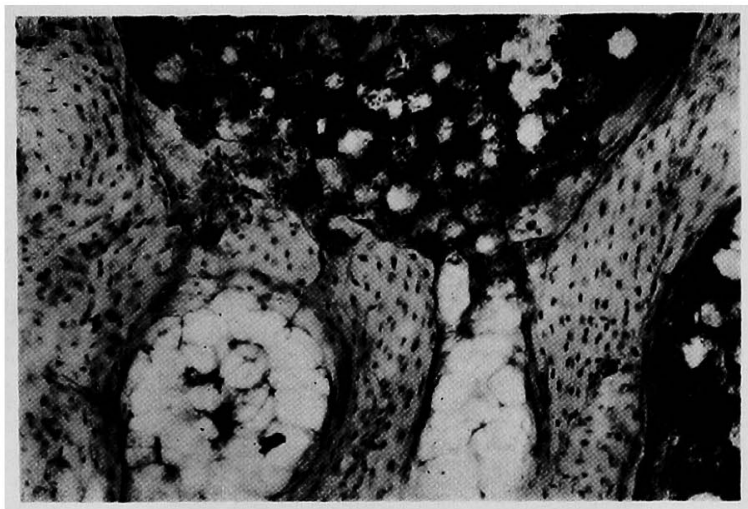

図17 術後 2 週間目の骨端部

骨端の靜脈洞には多く血球がつまり少いところもあり不 均一である

(H.E 染色 $\times 100)$

腿回旋動脈と骨幹栄䬭動脈の分布領城の境にあたり これより遠位の骨幹栄養動脈支配域では血球が非常 にすくなく，阻血部の静脈洞は不整いであつて，中 に含まれる血球には変形と染色性が異常となつてき ている.

○2週間目 骨端部にあ影響がおよんできてい

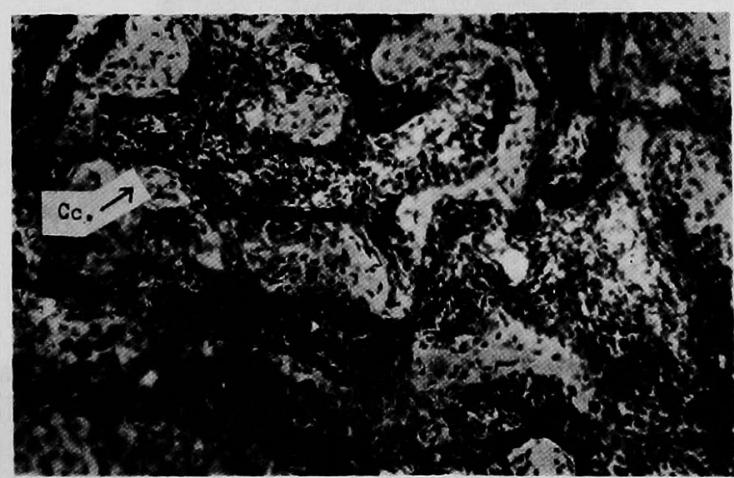

図18 術後 2 週間目の骨中間部遠位部

骨切部近くで骨梁周囲は絬合織性巨細胞で取り围まれて いる $\mathrm{Cc}$ 結合織性巨細胞 （H・E染色 $\times 100 ）$

る.ここにある静脈洞には正常より血球が多くつま り，反対にすくないところああつて不均一である （図17），骨中閻部までゆくと，静挀洞が他 と区別 できぬほど血球で充満しなんとなく污く，遠位に ゆくと次第に強くなる，その遠位では血球はこわれ て変形し，阻血状態が続いている．太い血営はみら れるが，これよりの分枝は殆んどみられず，周囲に 
は何もない，切口近くの骨梁周囲は結合織性巨細胞 がこれを取り囲み青く浱染している（図18）。

O3 週間目 乙の頃になると関節軟骨が幾分うす くなつている，特に骨頭の中心部で体重負荷のある ところである. 骨端と骨中閒部の境にある血管は太 く，充血は骨端にまでおよび，骨梁は䯣腔を不規則 にとり囲み，乙の中の静脈洞は画一的な特有の構造 を失い，波状になつたり周囲の骨梁に固着したりし て，骨切術の影響が相当あることを示している（図 19）．骨頭への血管は拡大し，骨端から骨間部にか けての充血が著明であつて，次第に遠位になるにし たがい阻血之線維性変性がみられる。

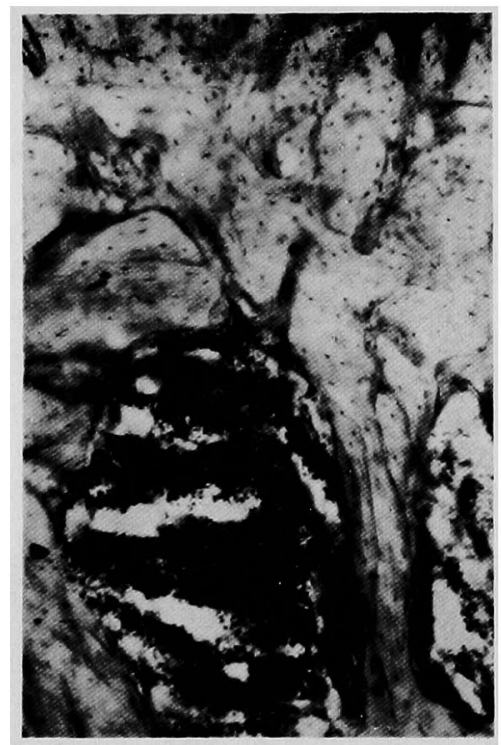

図19 術後 3 週間目の骨端部

骨端の靜脈洞は波状になつたり, 周囲の骨梁飞固着 したりしている（E-E 染色 $\times 100 ）$

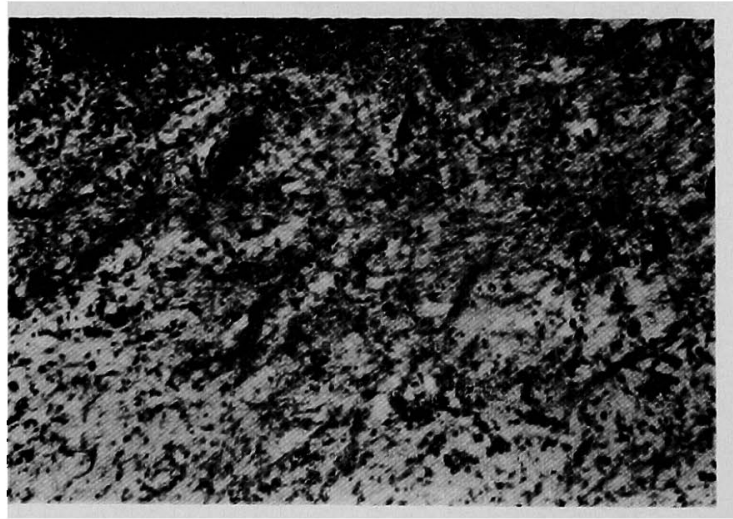

図20 術後 4 週間飞就ける骨中間部

阳血の強いところは均一的な線維性变化を示している $($ H-E 染色 $\times 100)$
○4週間目，骨頭より骨中間部の近位に加けて充 血が非常に著明である。こてにある静脈は形をくず しており, 症例によつては充血と阻血が湿在してい るのあある．阻血の強い骨中間部には壊死，空洞形 成のみられるあのもあり，その周囲は結合織やリン 八球で充満しているが，多くの症例では均一的は線 維性变化で占められている図 (20).

○6 週間目 関節軟骨の中間層は並びがすとし乱 れ，細胞の肥大と核が丸非をおびてきている。骨端 の骨梁は怪い萎縮がみられ，静脈洞は充血があり， 構造が不鮮明になつている。しかし，一時より幾分 清浄になつてきており，血球の濃淡をみとめる（図

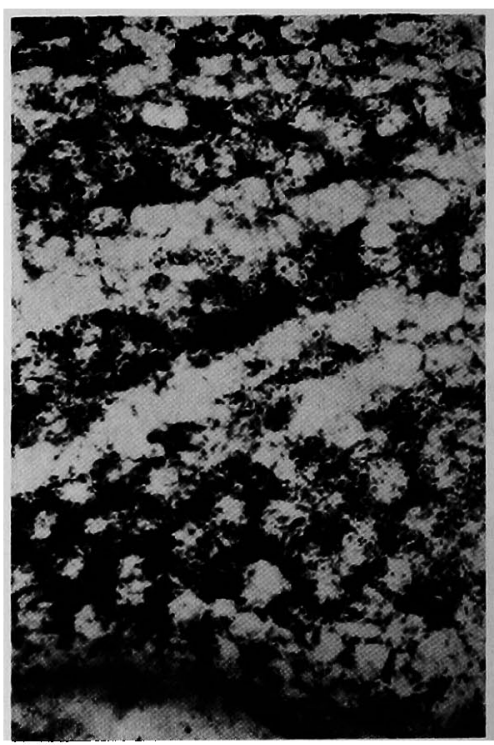

国21 術後 6 週間目の骨端部 最盛期のものより幾分清浮炕なつてきているが静脈 洞が不鮮明で血球に澴淡がある（H-E 染色 X100）

21）骨中間部には一時ほどの充 血はなく，そ のピークは過ぎているようである，結合織性に なつたところへは太い血管侵入がみられる。

○8週間目 関節軟骨は大分整頓されれてきて いるが，表面の滑かさは正常でなく，最深層が すこし厚いようである．骨端の静挀洞は大分回 復しているが，正常のあの上比校すると污く見 える. 充血も目立たなくなつている(図22). 既ち充血期はほぼ去り，あとは骨中間部遠位に 扣ける線維性変化と增殖した血管を残してい る. しかし阻血の強い症例では，循環障害の修 復のため依然として血管の拡大が怪いけどあ る. 


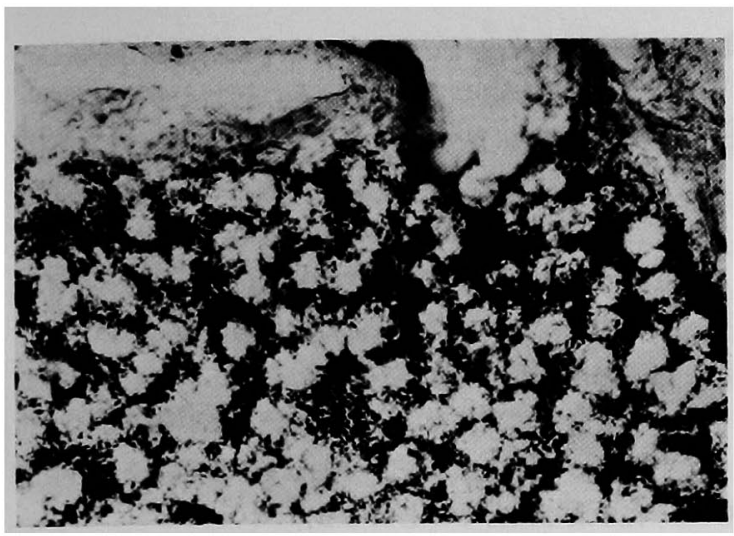

図22 術後 8 週間目の骨端部

骨端にある靜脈は大分回復しているが少し污い （H- $\mathrm{E}$ 染色 $\times 100 ）$

O10週間目，骨頭軟骨と骨踹骨梁は正常にふえつ ている，静哌洞にも型のくずれや充血がほとんどな い. 骨中間部にも怪い線経性変化はあるがその他は 正常に近い（図23），骨中間部にある新生血管 む太 さ走行などにおいて，以前よりあつたあのと次第に 区別ができぬように安定状態になつている。

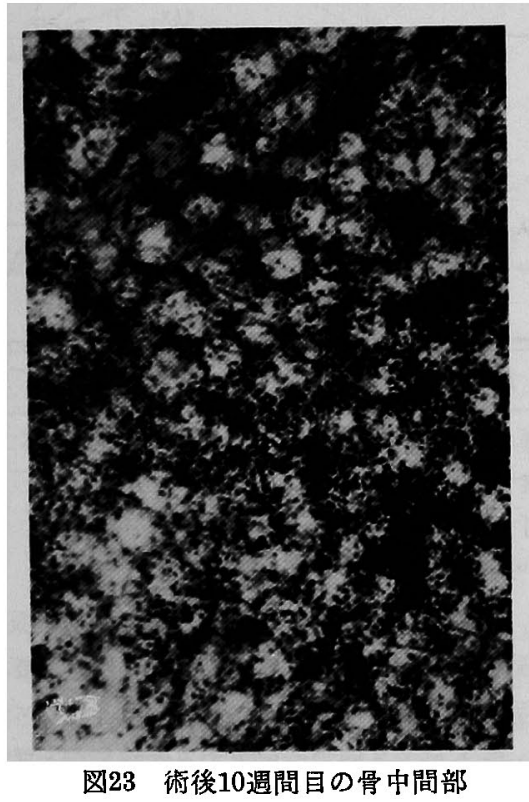

骨中間部に軽い線維性変化はあるが正常に近い様相 である

(H-E 染色 $\times 100)$

○鋼綵挿入後 5 週間のむの

鋼線のみの挿入例では，骨頭への変化の最も大き いと思われる 5 週間目のものを選んだ.

銅線は大転子と頸部の境を䨘ぬいており，この部 の鋼線周囲には軟骨性結合織に似た組織がこれを取
り囲み，その周囲の䯣腔は型が不揃いではある が破壊されているわけでなく，充血は見当ら ぬ.

骨頭・骨中間部の允血はほとんどみられず， 血管の変形むない. しかし，骨頭の表層に向う 血管は拡大しているのもあり，怪い影響があつ たとみてよい(図24).

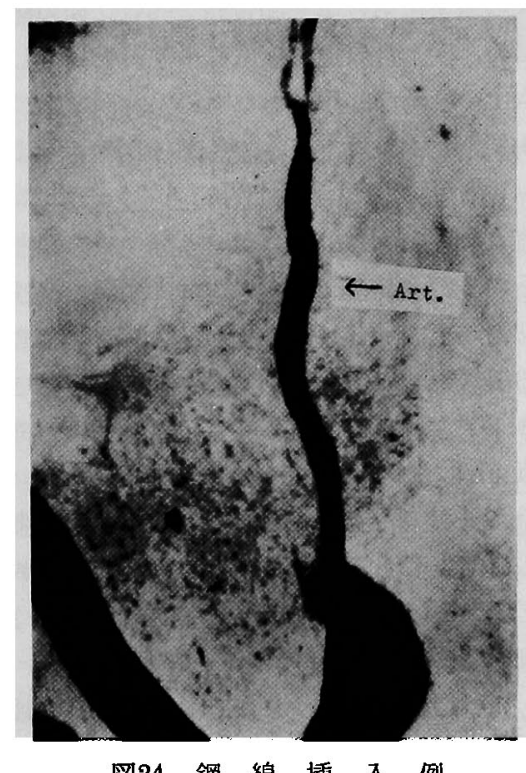

骨端より骨頭の表層に向つている血管で軽い拡大あ りArt.骨頭表層へ向う血管

(SPALTEHOLZ の標本 $\times 100)$

3）勁物実験総括

近位骨端㳄骨線が㚣全に閂銷消失している成熟家 鬼について転子間骨切術をやり，骨頭から頸部さら に轱子部における血液循環の様相をみた結果次の絬 論を得た.

○大腿骨㤝子間骨如術をすると，骨頭・骨中間部 は充血を示し，8週閒目ぐらいまでは続き，そのピ 一クはおよそ4〜 5週間目である。

○関節軟骨は $3 \sim 4$ 週間目が変化が強く，体重真 荷部がうすく，とれは運動・体重負荷の異常のため に栄養循環状態が変わるためであろう.

○初期より最盛期にみられる血管の拡大・蛇行は 主に分枝にみられるもので，主忮と区別ができぬこ とになり，次いで血管の増殖状態へすすむ.

○骨中間部では，骨幹栄荃動脈に支配されている 領域が阻血が相当続き，あとは線維性組織がとつて 代るようになる。 
○骨頭勒帯動脈は骨頭には侵入せず，ここの栄食 には全く関与していない.

○骨頭動脈では背側のものよりも腹側のものがよ り太く，拡大の程度も著明である。

\section{4. 変形性段関節症に対する䎐子間骨 切術の症例}

我々の教室に扰ける大腿骨転子間骨切術の症例は 多くなく，変形性股関節症に転子間骨切術をして 1 年半以上の経過を観察できたものは 9 例であつた。 男性 4 例之女性 5 例である. 手術時平均年令は 35.6 才で，7例は片側 2 例は両側性である，病歷や「X」 線写真上り，先股脱によるもの6 例 - 一次性之思わ れるもの1例・其他 2 例であつた，手術方法は，外 反骨切術 5 ・ 内反骨切術 2 ・移動骨切術 2 である. 術後の観察期間は 1 年 8 力月より 5 年 4 カ月で, 平 均は 2 年 3 カ月であつた.

調查方法

転子間骨切術の前後において, 疼痛・股関節の可 動性・日常生活機能・患者自身の手術にたいする評 価などについて調查した。

調査方法の基本は Shepherd - 清水のものを参考 としこれを日本に合うように改め患者の状態を最 あ詳細隹観察できるようにした。 この結果，股関節 の運動汇関するものが多く入り，想像以上に点数が 辛くなつた。

1) 疼痛

無痛の屯のを「0」とし，体重負荷なしでも疼痛

表 1 疼痛

\begin{tabular}{|c|c|}
\hline 0 & 無痛でほ㴽正常である \\
\hline 1 & 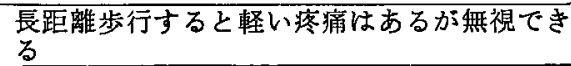 \\
\hline 2 & 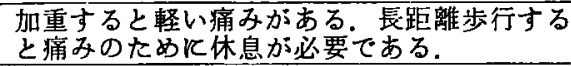 \\
\hline 3 & 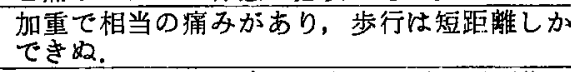 \\
\hline 4 & 加重をしなくても病みがあり歩行は不可能で \\
\hline
\end{tabular}

判定術後点数

\begin{tabular}{|c|c|c|}
\hline 侵 & $\begin{array}{l}0 \\
1\end{array}$ & $\begin{array}{l}\text { すへてのもの } \\
2 \text { 点以上の改善 }\end{array}$ \\
\hline 良 & $\begin{array}{l}1 \\
2\end{array}$ & $\begin{array}{l}1 \text { 点以上の改善加同点 } \\
2 \text { 点以上の改善 }\end{array}$ \\
\hline 可 & $\begin{array}{l}1 \\
2 \\
3\end{array}$ & $\begin{array}{l}\text { 減点のむの } \\
\text { 同点加改善 } \\
1 \text { 点改善 }\end{array}$ \\
\hline 不可 & $\begin{array}{l}2 \\
3 \\
4\end{array}$ & $\begin{array}{l}\text { 減点 } \\
\text { 同点か诚点 } \\
\text { 寸へてのもの }\end{array}$ \\
\hline
\end{tabular}

があり全く歩行できぬすのを「4」として分類した （表 1). 判定にはどの項目 毛回じように優・良・ 可·不可とした。

との結果は片側のもの之両側のものでは異るとと が判つた。 片側のあのでは 1 例の良を除けばすへて 優であつたのに比して, 両側性のあのはすべて不可 であつた，何故ならば，両側性のあのに招いては， 手術側については優あるいは良であつてあ，非手術 側を考虑に入れた場合には，術前よりはるかに悪化 しているさらに，一度怪块していた手術側む再び悪 化の道をたどることになる.

2）関節可動性

表 2 のよに届曲外転に重きをおく採点方法をと り，正常でほほ 100 点満点になるようにした。

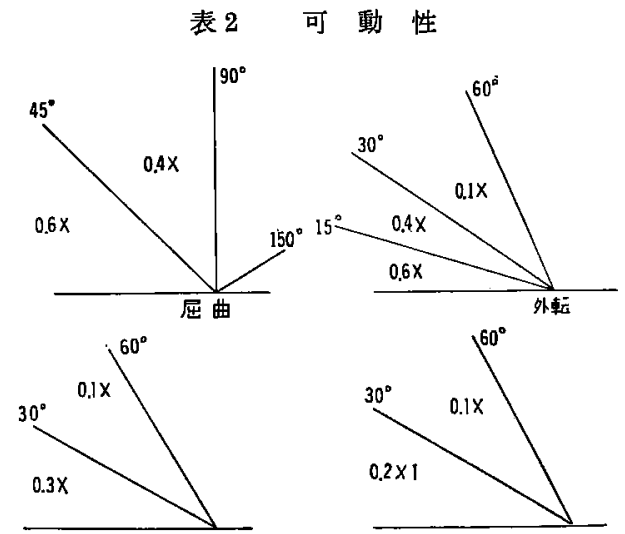

外 旋

内転 内掟

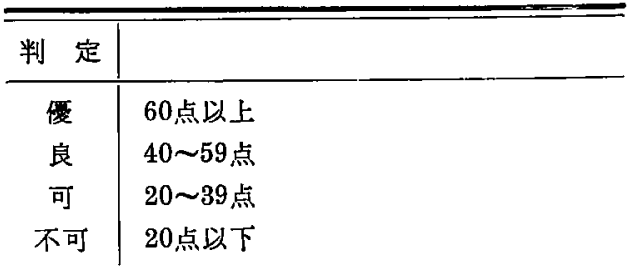

可動域の数字からは，6 例が優で 3 例が良であつ た。可期域の改善ということ加らると改善・変化 なし・低下が各 3 例ずつ分散するけれども，平均値 をとると 5 度ばかり制限が強くなつている，高令者 や手術後江循環障害のみられた症例に著るしく，そ のうちでも届曲制限が最も生じ易いようである。経 過を追つていると，2年間位は順調であつて，その あとで狭い範囲の運動可動域になつているのああ る. し加し，多くのあのは半年後あたりより次第に 好枟しており，手術損傷やギプス固定による便さが 次附にとれてゆくためであ万う。 


\section{3）日常生活機能}

特に日本人の生活に必要なむのを表 3 のように 8 項目にわたつて調べた。これをみると，股関節の運 動障害と疼痛があれば非常に影響を受け易いあのば かりで構成されている。

表 3 日常生活機能

1）歩行方法：杖なし (0) 片杖 (1) 両杖 (3) 両松葉杖 (5)

2）歩行距離：2km以上(0) $200 \mathrm{~m}$ 以上(2) $200 \mathrm{~m}$ 以下 (3) 不能 (5)

3）階段の昇降 可 $(0)$ 困(1) 不(3)

4) 正座可 (0) 困(1) 不 $(3)$

5) 踞可 (0) 困(1) 不(3)

6) 跛行 烸(0) 㪕(1) 中(2) 重(3)

7) 糊。着脱可(0) 困(1) 不 (3)

8）作 業 重労 (0) 普作(1) 軽作 (2) 不(5)

\begin{tabular}{|c|c|c|}
\hline 判定 & 点数 & \\
\hline \multirow{5}{*}{ 绶 } & $0 \sim 1$ & すべて \\
\hline & $2 \sim 3$ & 1 点の改善 \\
\hline & $4 \sim 6$ & 2 点以上の改善 \\
\hline & $7 \sim 10$ & 3 点以上の改善 \\
\hline & $11 \sim 13$ & 5 点 " $"$ \\
\hline \multirow{3}{*}{ 良 } & 6 以下 & 改善のあつたもの \\
\hline & $7 \sim 9$ & 2 点以上の改善 \\
\hline & $10 \sim 15$ & 3 点 " " \\
\hline \multirow{2}{*}{ 可 } & 17以下 & 1 2 点改善 \\
\hline & 32以下 & 術前と同点のもの \\
\hline \multirow{2}{*}{ 不可| } & 17以下 & 3 点以上の悪化 \\
\hline & 17以上 & 悪化したもの \\
\hline
\end{tabular}

結果は優 5 ・良 2 ・不可 2 というととになつた。 この不可の 2 例はすべて両側性のむのであつて, 項 目では最む成績の悪いのは践踞と階段の昇降であ つて主に股関節における開排運動の制限が影してい る.

4）患者自身の評価

片側性のものはすべて患者は優と答えており，両 側性のむのでは可である之評価している，それあ， 手術後半年か 1 年の間は結果はよいが, 反対側の疼 痛か増すようにはつてか は次第に評価むおちてき ている。一般には疼痛について最む感謝し, 反つて 悪化するのは運動範囲である.
表 4 患者自身による評価

\begin{tabular}{|c|c|}
\hline 绶 & 満足して招り，全く手術に感謝している. \\
\hline 良 & $\begin{array}{l}\text { ほば満足している. 少しは症状が残つている } \\
\text { が手術を受けてよかつたと思う. }\end{array}$ \\
\hline 可 & $\begin{array}{l}\text { 都分部には悪化しているところむある. 全体 } \\
\text { としては良くなつているが満足していない. }\end{array}$ \\
\hline & 上り悪化し， \\
\hline
\end{tabular}

5)「 $「 \mathrm{x} 」$ 線所見

○骨硬化，全く認めない1例を除きすべて骨硬 化を呈している．しかしその絶対值を計測すること は不能であつて，周囲の濃さと比較して，術前後に 果して改善されているかどうかるみるわけで, 点数 の差であつて表わし表 5 のように分類した.

ての結果は優 5 ・良 4 であって，観察期間の長短 が影響するので詳しくは判らぬが，大体 2 年間で改 善されるのはその効果がみられるようである. そし て, 片溉性のものは好転した状態が続くが，両側性 のあのは一度よくなつても又悪化したり，好転の具 合が急に止つてしまうようなことがある。

表 $5 \quad \mathrm{X}$ 線上ての骨硬化

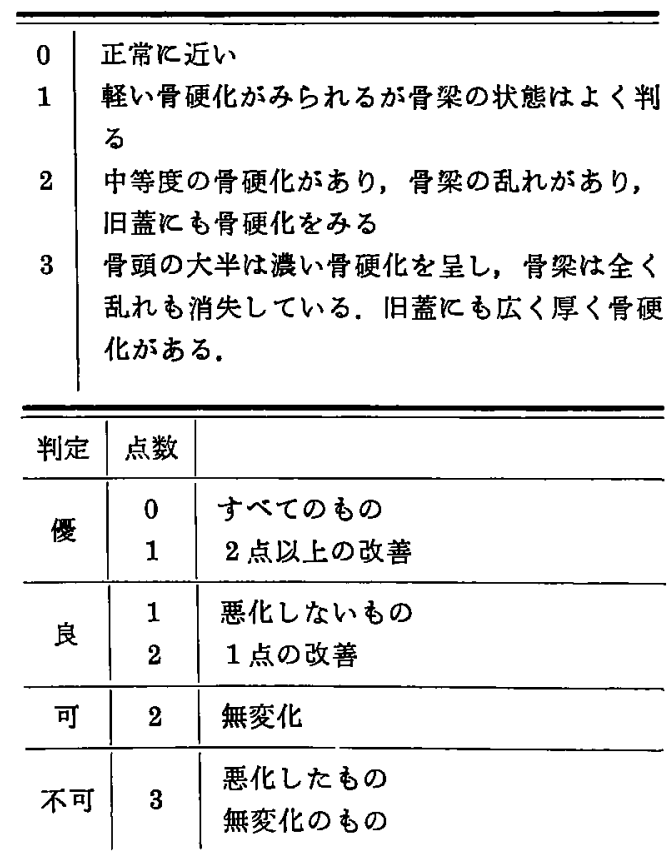

○ 関節裂隙，表 6 のように分類すると，優 6 ・ 良 2・可 1 で悪化したあのはない，術前と前後で無 変化化近いものがあり，一時より狭くなつたものも あつたがとあに両側性のあのであつた。 
表 6 関 節 裂 隤

\begin{tabular}{l|l}
\hline \hline 0 & 渗んど正常である. \\
1 & 体重負荷に限りすこし狭い \\
2 & 全体的に狭く, 体重負荷部に著明 \\
3 & 関節裂腺は消失している.
\end{tabular}

\begin{tabular}{|c|c|c|}
\hline 判定 & 術後点数 & \\
\hline \multirow{2}{*}{ 倕 } & 0 & すべてのもの \\
\hline & 1 & 1 点以上の收善 \\
\hline \multirow{2}{*}{ 良 } & 1 & 悪化のないむの \\
\hline & 2 & 1 点以上の改善 \\
\hline - 可 & 2 & 悪化のないもの \\
\hline \multirow{2}{*}{ 不可 } & \multirow{2}{*}{3} & 悪化したもの \\
\hline & & すべてのもの \\
\hline
\end{tabular}

この関節裂隙の拡大と臨休症状とは関係が深く， 骨硬化・関節裂隙拡大とむに経過がよりれは臨非紹 果むよい(図25).

6) 手術症例の総括

変形性股関節症に対する転子間骨切術の結果をみ ると, 疼痛についてはすべての症例において效果が みられた。両側性のものであ手術側についてのみ考 えるならば非快している。乙の手術效糢とその術式 との関連性はない.

反対に，手術に併発する障害は運勘制限の強くな ることで，特に屈曲障害が顕著であり，日常生活に おいては蹽踞の制限として表現される。

「X」線像などにおける所見では，骨䂠化，関節 裂隙などの改善があり，臨床症状との相関々係がみ られ，関節裂隙は術後数力月より应大し初め骨硬化 はこれより初果発現は幾分逯く，両者ともに 2 年位 で固定すればそのまま続くものが多いけれどあ，両 側性のむのでは再発が生じ易く，改善の度すすくな い. 手術による骨頭の位嗢変换によつて出来る裂隙 でなく，関䬣軟骨の再建によるものと思われる。

両側性のものにおける単なる転子間骨切術の症例 ではすべてよくなく，術後における体重負荷という ことからして別の治療方針が必要である。

\section{5. 文献的考察ならひに考按}

変形性股関節症のうちで, 一次性のあのは日本で はその率が非常に低く，抑は谷 $8 \%$ ，島は $13 \% ，$ 伊 藤 $8 \%$ ，上野は15\%という数字をあげている。乙れ を外国の統計と比較してみると，Lloyd-Robert の

陸夫

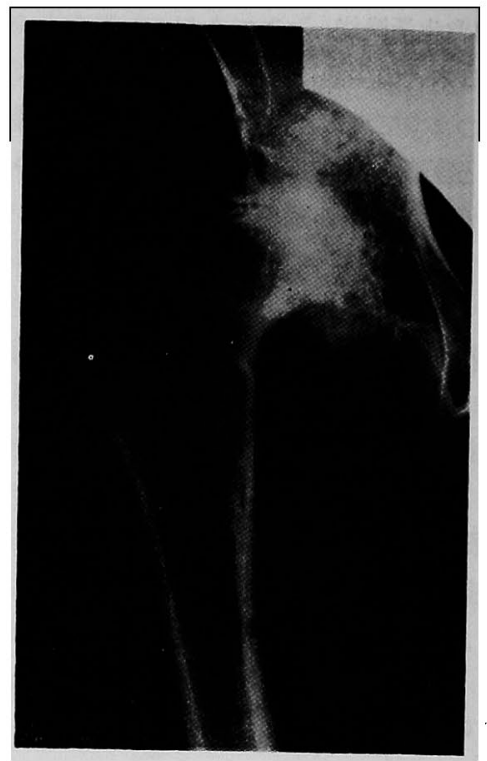

図25 a 臨床 症 例 術前 関節裂隍は全体的に非常にうすく，骨硬化とも骨頭 と旧蓋に著明である

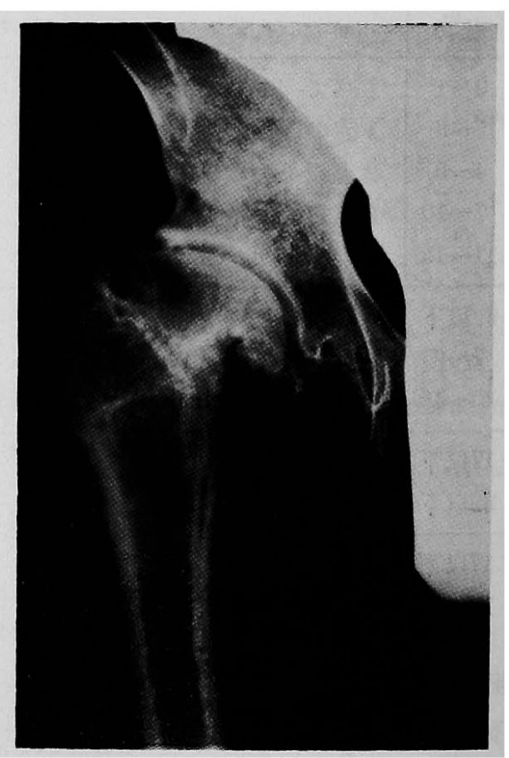

図25 b 臨 床 症 例 術後 3 年

関節裂腺は著明昿大し，骨便化す軽く残るのみて 臨休症状む非常浮好転している

58.5\%, Nicoll の 59.5\%, Plews の 48.5\%などで非 常に高率である，逆に，日本人のあのは先股脱に由 来するものが断然多く，股関節症の治療・研究すと てから入つている.

さて，この一次性変形性股関節症についても，そ の成因について沢山の视があり，多元的原因あ考元 られている。 
機械的刺戎説は Pommer (1918) 亿初まるもので, 労㗢者に高率に関節症がみられるととから，関節軟 骨に持続的な機峨的刺戟が加わるととにより，軟骨 下にある骨䯣が刺载されて変形性関節症になるとい う. Burckhardt む軟骨損傷より進行するとし, Lang あ成人における過重の緊張による軟骨損鹪を一次的 な意義としてみとめている. Bauer は年令と外傷に よる顿骨の磨堿にその原因をみとめ, 変性的な関節 笑患と呼ぶのがふさわしいとのべている.天児す上 肢を激しく使用する抗夫関節症が多発しているて と加ら，機械的刺戟をこの一因として認めている.

ての説に反対する人もあつて, Heine は重労㗢者 と非労働者の各々 100 例滛解剖的な有意義の差のな かつたととを報告している.

内分泌異常説としては， Silverberg が一連の研究 をしており，成熟甘日ネズミに高脂肪食を与えて関 節症との関係を調へ，関節症の発症とその進行の早 くなるととがあり，成長期にあるものに Radiothyroidectomy をすると関節症の発生がすくないが, 成 熟したすのに操作する之対象例のすのよ頻発すると いう，卵巣や精腺を摘出すれば軟骨の変性は遅れ， 反対に Teststeron を投与すると関節の老化が促進さ れ, 変形性関節症の発生率む高くなるという. Weine は末端肥大症の進行した例に関節症様の变化があつ たといい，螮人更年期にもそのような症状があると 報告している。

血行障害説を唱える人は多く，Wollenberg (1909) による犬の㮏蓋骨血管の結禁実験 から, Axhausen の追試実験, Goldhalt の骨頭へ行く血管の結禁実験 とあり，みな関節症に似たあのを作りだしている. Leriche は血管神経障害による循謤障㕩を原因とし, Law は血行障害による罗死加関節症になるとい う. Rimann 肥厚型のむのは動脈硬化にその源を求 め, Sell は実験的高血增のあのは関節症を作りだし ている、藤本は食塩負荷にて関節症を生じさせてい る. Schmitz は，関節周囲に血管の閉塞性変化があ り，このため循環障害をおこして細胞の $\mathrm{pH}$ が変わ り，骨㳄骨の肉眼的顕徽鏡的構的を变えるととにな るという. Harrison な関節軟骨の変性に応じて juxa-chondral に血管性反応がおこり，てれより次第 に骨頭の変形へと進行するという.そして Walmsley は，骨頭の血液供給は年令と共に減少するとのへて いるのに対して, Truetaはてれに反対している.

このように関節症の成因については色々とのへら

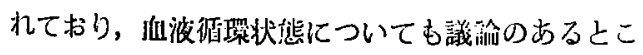

ろである，この血液循環状態を調ぺるのに種々の方 法がある. 動脈を造影する方法としては, Rook や Hipp の報告があるが実用とはならず，静脈造影と しては Ducci に初まり, Hulth や Harrison により 行われているが静脈であるということで万全の信頼 はおけないのである，土居によると，変形性股関節 症では静脈性遑流の障害が著明であつて，正常にあ る静哌弁をみとめずうつ血状態化あると想像され， Tucker に初まる Radiation Clearance でも結果は 同じであるという．との方法では静脈性うつ血状態 であつて，動脈性のあのは計測できぬのである。

他化 Larsen の骨内压気定法, Woodhouse の酸素 圧測定法などあるが，長短所があり操作の割りには

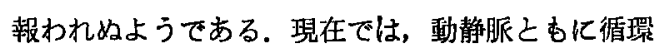
障害があるということになつている。

変形性股関節症の患者の最大の脳みは疼痛であつ

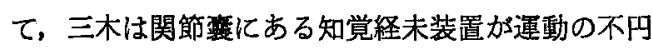
滑さにより刺戟されるためにおてるが，さらの骨頭 之関節輁における阻血むその原因になるであろうと のべている.

したがつて，変形性股関節症を治療するにあたつ ては，機械的要素について考えるとともに，生物学 的要素についてもこれを改善するようにしなければ ならない。

Mc Murray はその手術効果を, 骨頭の外反之大 腿骨軸の内方移動によつて，遠位骨片に Lig. transverse acetabuli で支持させるのであるとのへてて おり, Pauwels は内転・外転骨切術を, 荷重面の搪 大之腸㴗筋の弛緩による免荷だとした。 このように， 現在もちいている転子間骨切術では, 生物学的要菜 については当初は何も考えられていなかつたのであ る.

しかし，Ottolenghi は転子䦎骨切術によつて骨硬 化など「X」線像所見が改善されるのは, 機械的要 装の他に生物学的要装についてあ洘える必要があり，

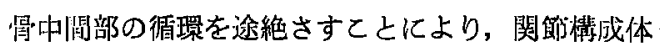
すへての循環状態が変わつてくるとしている，豐田 は幼弱家兔の転子下骨切術に上る些験加ら, 牙術後 $3 \sim 5$ 週間後が骨頭・骨中間部の光血は最も強い之 いい, 黒田は同じ実験に p32 を使用し, 骨切術は大 腿骨頭や骨中闇部の血行を改善することは確かで, 臨床的にあこの部分に血行障害のある症例には利用 洒值のある手術方法であると論じている.

私は，変形性股関節症にたいして耺子間骨切術を

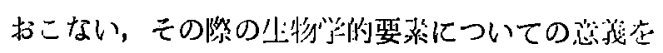


知るため動物実験もあわせおこなつた，成熟家鬼 では骨端軟骨線は完全に開銷しているので, 変形性 股関節症の場合と同じような変化が転子間骨切術後 亿生ずると思われる，動物実験で転子間骨切術をす ると，骨幹栄盖動脈の上行枝は完全に切断され，と の動脈の分布栄養している骨中間部は阻血に陌いり， 反応性温頭加ら頸部に加けては血管の拡大，充血 がみられる，そのピークは術後 $4 \sim 5$ 週であつて， 8〜10週もすると反応性血管拡大はほほ正常汇近い あのに㸟る。

臨床症例においては，その手術方法には関係なく 疼痛が軽減しており, 忽論, 軟部組織の緊張緩和や 術後の安静などあ関係しているいとはうかがわれる けれども，転子間骨切術による血行循環障害にたい して効果があるように思われる. 即ち, 生物学的要 素の方から考えると，単に骨切術をするだけで効果 がある筈であつて，各々の症例における手術々式は 機械的要素を中心に考えればよく，外反か内反ある いは転移のみにする加は，体重負荷時におりる骨頭 の単位面積あたりにたいする最小の圧迫力を求める ようにすればよいわけである.

転子間骨切術における最も一般的な欠点は，術後 に運動可能範囲が狭くなることであつて, 術前の運 動制限の少いあの（特に屈曲）であつてはならず, これが狭いと関節固定術に似た状態になるおりであ る. 実際, 術前之術後においてその運動可能域をだ して平均してみると， 5 度程度の制限增加があるが， それ以上に日常生活における不便さとして患者は感 じている.

$\lceil\mathrm{X} 」$ 線像においては，関節裂隙・骨硬化・骨怔 色などの改善がみられるが，関節裂隙の拡大を除い ては徐々である. この関節裂隙の拡大は術後数力月 よりみられるものである，その原因は関節軟骨再生 と考えてよく，骨頭の位置の枟换によつても拡大さ れうるけれども，枟子間可術（骨切）の適応を层ふ 埸合に骨頭の枟換によつて関節裂隙の搪大するよう な症例は初加ら除いていて，そういう理由で拡大 するようなととは教える必要はない，術後約 1 力年 位は広くなる傾向があり，あ之はそのままの状態が 持続するようである，骨硬化の改善はさらに徐々で あつて，撮影条件や状態を常に同一にするようは心 掛けて撮し. 数枚を横に並へて比校し確に煀くなつ ているのをみて結論を出しているが，あるていど改 善するとそこで固定し, カの状態が悪ければ又逆戻

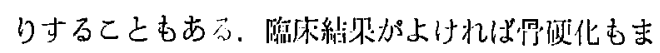

た改善が著るしい。

両側性の股関節症にたいする手術は特に慎重を要 し，片側のあのと同じように手術すれば必ず反対例 の悪化を招いている. 非手術側を悪化させぬように するには，支持脚を 1 側作ることであつて，固定術 が最もよく，次いでもう 1 側涓切術・人工骨頭， Cup Arthroplasty などを和てなうのがよい，日本人 の変形性股関節症においては，二次性のむの加断然 多いとよや手術例では変形が著明であることから骨 切術の適応之なるあのが比校的すくなく，片側のみ の場合でも Cup Arthroplastyをやつたり人工骨頭 に置換するものが割に多い，さらに，日本の生活樣

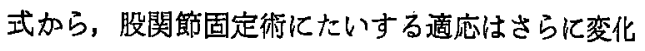
してくる. 即ち座ることの多い日本人にたいしては, 外人よりも股関節固定術における適応選択が難しく なり，それだけにより慎重な術式決定計面が必要と なるわけである。

\section{6. 結 語}

成熟家鬼にたいして転子間骨切術をおこない，骨 頭および骨中間部におよぼす影響を，脈管学的なら びに組織学的に研究し，てれを変形性股関節症にた いする転子間骨切術と比較検討して次の所見を得 た.

1）成熟家鬼にたいして転子間骨切術をすれば， 骨頭および骨中間部へゆく動脈は拡大するが，その 強さは術後 $3 \sim 5$ 週間目が最も著るしく, 骨頭への 影響は骨中閒部より遅くて柽い，10週間目にるなれ ばその意義はなくなるようである。

2）組織像におりる所見では，骨頭軟骨にまでそ の影響がおよび，骨頭・骨中間部の充血と骨幹栄養 動脈に支配されている部分の阻血状態がみられる。

3）変形性股関節症に転子間骨切術をした症例で

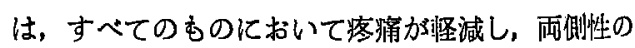
あのにおいては反対倒㴼みをまし，結局は単に忶 子間骨切術をするのみでは䭾目である，支持㑢を 1 侧作ることである.

4）㤝子間骨切術では運政俐限が最む作発し易い 障害であつて，そのうちでも屁曲障害がよくみられ る.

5）転子間骨切術とその術式・手術の角度や転移 の大小と手術効果之は相関々係がみられない，転子 間骨切それ自身が相当の意味をもつていると思わ扎 る.

6）従つて，乎術方法を汹めるときには，機椒的 
要丠として骨頭への免荷をはかるようにし，さらに 生物学的要素として骨頭への血行循環障害を改善す るよう考虑する必要がある。

1）天児民和住か：变形性设関節症 外科研究の進 歩, $6: 120,1958$

2）天児民和：変形性设関節症の治療の選択 日整 会詰 $36: 623,1962$.

3）士屋通泰：変形性役関節症の病龍生理学的研究

4）藤本憲司任か：変形性吺関節症の成因について 日整会誌，36：607，1962.

5）平山正樹：大腿骨頭の血管系化関する研究.日 整会誌，39:297, 1965.

6）猪将忠ほか：関節液から診たる変形性関節症. 日整会誌，36：611，1962.

7）伊丹康人：变形性没関節症炍関する研究 日整 会誌, $36: 737,1962$.

8）伊藤鉄夫：2 次性変形性没関節症の治療 整形 外科, $15: 12,1964$.

9）川北篤：殿関節形成術に㧍ける脈管の態度に関 する聿験的研究 中部整㷋誌，6:259，1963.

10）児玉俊夫：变形性没関節症の分類须て 中 部整災誌，3：168，1960.

11）近藤鋭矢：変形性没関節症に対する我が教室の 治療方針 中部整災誌 $3: 174,1960$.

12）黑田澄雄：成長期江招ける大腿骨中枢部骨切術 が大腿骨頭並び飞中枢骨中間部血流飞及ぼす影 徱飞ついて 北海道整災誌， 7:220，1962.

13）松丸寞：変形性没関節症の治療 中部整災誌， $3: 182,1960$.

14）三木威勇治 : 变形性设関節症の病態生理 日整 会誌, $36: 613,1962$.

15）水野样太郎：变形性设関節症にたいする治癫 中部整災誌 $3: 170 ， 1960$.

16）清水源一郎：股閃節改造術の造隔成綪 中部整 災誌，4:369, 1961.

17）玉置拓夫经加：変形性没関節症の手術的治療. 整形外科, $16: 185,1965$.

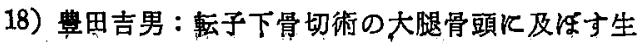
物学的影翻々ついての実験的研究。北海道整災 誌, $5: 97,1960$.

19）上野良三：砓関節症の治療経験 整形外科，16 $: 81,1965$.

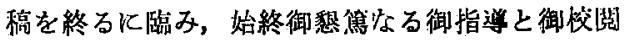
を賜わつた恩師児玉俊夫教授，ならびに直接御指導， 御鞭撻をいただいた田辺㓮造助教授飞衰心より感謝 の意を表します。

文献

20) Adams, A. etal. : Intertrochanterie Osteotomy for Osteoarthritis of the Hip. J. Bone and Joint Surg., 40-B : 219, 1958.

21) Arden, G., P. : Variations in Joint Space of the Hip. J. Bone and Joint Surg., 39-B: 750, 1957.

22) Bauer, W. and Bennett, G. A. : Experimental and Pathological Studies in the Degenerative Type of Arthritis. J. Bone and Joint Surg., $18: 1,1936$.

23) Blount, W. P. : Osteotomy in the Treatment of Osteoarthritis of the Hip. J. Bone and Joint Snrg., 46-A : 1297. 1964.

24) Bobechko, W. P. and Harris, W. B. : The Radiographic Density of Avascular Bone. J. Bone and Joint Surg., 42-B : 626, 1960.

25) Brodetti, A. : The Blood Supply of the Femoral Neck and Head in Relation to the Damaging Effects of Nails and Screws. J. Bone and Joint Surg., 42-B : 794, 1960.

26) Campbell, J.P. : et al. : Treatment of Osteoarthritis of the Hip by Osteotomy. J. Bene and Joint Surg., 38-B : 468, 1956.

27) Chandler, S. B. and Kreuscher, P. H. : A Study of the Blood Suplly of the Ligamentum teres and its Relation to the Circulation of the Head of the Femur. J. Bone and Joint Surg., 14 : 834, 1932.

28) Claffey, T. J. : Avascular Necrosis of the Femoral Head. J. Bone and Joint Surg., 42-B : 802, 1960.

29) Coolbaugh, C. C. : Effects of Reduced Blood Supply on Bone. Am. J. Physiolog,, 169:26, 1952.

30) Cumming, J. D. : A Study of Blood Flow Through Bone Marrow by a Method of Venous Efferent Collection. J. Physiol., 162 : 13, 1962.

31) Ferguspn A. B. : The Pathological Changes in Degenerative Arthritis of the Hip and Treat- 
ment by Rotational Osteotomy. J. Bone and Joint Surg., 46-A : 1337, 1964.

32) Harris, W. R. and Hobson, K. W. : Histological Changes in Experimentally Displaced Upper Femoral Epiphyses in Rabbits. J. Bone and Joint Surg., 38-B : 914, 1956.

33) Harris, N. H. and Kirwan, E. : The Results of Osteotomy for Early Primary Osteoarthritis of the Flip. J. Bone and Joint Surg., 46-B : 477, 1964

34) Harrison, M. H. M., Schajowicz, F, and Trueta, J. : Osteoarthritis of the Hip: A Study of the Nature and Evolution of the Disease. J. BBone and Joint Surg., 35-B : 5५8, 1953.

35) Harty, M. : Blood Supply of the Femoral Head. Brit. Med. J., 5 : 1236, 1953.

36) Hirsch. C. : Intertrochanteric Osteotomies in Osteoarthritis of the Hip. Acta Orthop. Scand., $30: 129.1960$.

37) Howe, W. W. et al. : A Study of the Gross Anatomy of the Arteries Supplying the Proximal Portion of the Femur and Acetabulum. J. Bone and Joint Surg., 32-A : 856, 1950.

38) Huggins, C. and Wiege, E. : The Effects of the Bone Marrow of Disruption of the Nutrient Artery and Vein. Annal. Surg., $110: 940,1939$.

39) Hulth, A. : Femoral Phlebography. J. Bone and Joint Surg., 40-A : 844, 1958.

40) Hulth, A. : Circulatory Disturbances in Osteoarthritis of the Hip. Acta Orthop. Scand., 28 : $81,1959$.

41) Judet, J., Judet, R., Lagrange, J. and Dunoyer, J. : A Study of the Articular Vascularization of the Femoral Neck in the Adult. J. Bcne and Joint Surg., 37-A : 663, 1955.

42) Kellgren, J. H. and Samuel, E.P. : Sensitivity and Innervation of Articular Capsule. J. Bone and Joint Surg., 32-B : 84, 1950.

43) King. T. and Dooley, B. : Observations on the Late Results of the Mc Murray Osteotmy for Osteoarthritis of the Hip. J. Bone and Joint Surg., 44-B 595, 1962.

44) Knot, H. : Osteoarthritis of the Hip. J. Bone and Joint Surg., 46-A : 1329, 1964.

45) Landells, J. W. : The Bone Cysts of Osteo- arthritis. J. Bone and Joint Surg., 35-B : 643, 1953.

46) Lang, F. J. : Osteoarthritis Deformans Contrasted with Osteoarthritis Deformans Juvenilis, J. Bone and Joint Surg., 14:563, 1932.

47) Lemoine, A. : Vascular Changes after Interference with the Blood Floow of the Femoral Head of the Rabbits. J. Bone and Joint Surg., $39: 763,1957$.

48) Leriche, R, : The Problem of Osteoarthritis Diseases of Vasomotor Origin. J. Bone and Joint Surg., $10: 492,1928$.

49) Lloyd-Robert, G. C. : The Role of Capsular Changes in Osteoarthritis of the Hip Joint. J. Bone and Juint Surg., 35-B : 643, 1953.

50) Lloyd-Robert, G. C. : Osteoarthritis of the Hip. J. Bone and Joint Surg., 37-B : 8, 1955.

51) Mackenzie, J. F. : Osteoarthritis of Hip and Knee. Brit. Med. J., $15: 306,1936$.

52) Mc Farland, B. : My Present Attitude to Osteoarthritis of the Hip. J. Bone and Joint Surg., 36-A : 476, 1954.

53) Mc Murray, T. P. : Osteoarthritis of the Hip Joint. Brit. J. Surg., 22 : 716, 1935.

54) Mc Murray, T. P. : Osteoarthritis of the Hip Joint. J. Boue and Joint Surg., $21: 1,1939$.

55) Milch, H. : The Post-Osteotomy Angle. J. Bone and Joint Surg., $26: 394,1944$.

56) Nissen, K. I. : The Arrest of Primary Osteoarthritis of the Hip. J. Bone and Joint Surg., 42-B 423, 1960.

57) Ottolenghi, C. E. et al. : Intertrochanteric Osteotomy in Osteoarthritis of the Hip. J. Bone and Joint Surg., 44-A : 855, 1962.

58) Palazzi, A.S. : On the Operative Treatment of Arthritis Deformans of the Hip Joint. Acta Orthop. Seand., $27: 291$, 1958.

59) Pauwels, F. : Neue Richtlinien für die Operative Behandlung der Koxarthrose. Verh. Deut. Orthop. Ges., 48:332, 1960.

60) Pearse, H. E. et al. : Thc Influence of Alterations in the Circulation on the Repair of Bone. J. Bone and Joint Surg., 13:68, 1931.

61) Plews, L. W. : Osteoarthritis of the Hip. Brit. J. Surg., $27: 682,1940$. 
62) Pómmer, G. : Die Funktionelle Thcorie der Arthritis Deformans vor dem Forum des Tierversuches und der Pathologischen Anatomie. Arch. Orthop. Unfall-Chir., $17: 573,1920$.

63) Pridie, K. H. : Etiology of Osteoarthritis. J. Bone and Joint Surg., 33-B ; 643, 1951.

64) Rhinelander, F. W. and Baregry, R. A. : Microangiography in Bone Healing. J. Bone and Joint Surg., 44-A : 1273, 1962.

65) Ring. P. A. : Operative Treatment of Osteoarhritis of the Hip. Brit. Med. J., 19:829, 1960.

66) Robbins, R. H. C., Piggot, J. : Mc Murray Osteotomy. J. Bone and Joint Surg., 42-B : 480, 1960.

67) Schmitz, F. : Beitrag zur Diagnostik und Behandlung des Hüftschmerzes, Arch. Orthop. Unfall-Chir., $46: 125,1953$.

68) Sell. G. : Beziehungen $Z$ wischen Kreislaufveränderungen und Arthrose-Entstehung. Arch. Orthop. Unfall-Chir., $52:$ 379, 1960.

69) Shepherd, M. M. : A Further Review of the Results of Operation on the Hip Joint. J. Bone and Joint Surg., 42-B : 177, 1960.
70) Silverberg, M. : Effects of a High Fat Diet on the Joint of Aging Mice, Arch. Pathol., $60: 828,1950$.

71) Silverberg, M. : Degenerative Joint Disease in Castrated Mice. Arch. Pathol., 65 : 438, 1958.

72) Trueta, J. and Harrison, M. H. M. : The Normal Vascular Anatomy of the Femoral Head in Adult Man. J. Bone and Joint Surg., 35B : 442, 1953.

73) Trueta, J. : Studies on the Eliopathology of Osteoarthritis of The Hip. Clinical Orthop., $31: 7,1963$.

74) Tucker, E. R. : Arterial Supply at the Fomoral Head and its Clinical Importance. J. Bone and Joint Surg., 31-B : 82, 1946.

75) Walmsley, T. : The Articular Mechanism of the Disarthroses. J. Bone and Joint surg., 10 : 40, 1928.

76) Wardle, E. N. : Displacement Osteotomy of the Upper Fnd of the Femur. J. Bone and Joint Surg.; 37-B : 568, 1955.

77) Wolcott, W. E. : The Evolution of the Circulation in the Developing Femoral Head and Neck. Surg. Gynec. and Obst., 77 : 61, 1943. 


\title{
Experimental Studies of the Biological Factors on the Intertrochanteric Osteotomy in Osteoarthritis of the Hip
}

\author{
By \\ Rikuo OKUDA \\ Department of Orthopedic Surgery Okayama University Medical School Okayama, Japan \\ (Director: Prof. Toshio Kodama)
}

\begin{abstract}
In the experiments conducted with adult rabbits for the purpose to elucidate biological factors of intertrochanteric osteotomy in osteoarthritis of the hip, the following results were obtained.

1) After intertrachanteric osteotemy performed on adult rabbits in about 4 to 5 postoperative weeks there can be observed the dilataticn of blood vessels in the epiphyseal and the metaphy. seal regions and hyperemia due. to it feaches its maximum, but by about 8 to 10 weeks it returns practically to normal.

2) Intertrochanteric osteotomy in man is most beneficial for serve pain and its ill effect is the limitation of movement. However, in the bilateral case its applicability should be decided with utmost care and it becomes necessary to obtain the hip joint having monolateral support. 3) In discussing about intertrochanteric osteotomy its effect is mainly taken up from its mechanical aspect, but its biological significance should also be given a due attention. Therefore, in discussing what operative proeedure needs to be selected, this latter point must be borne in mind.
\end{abstract}

